\title{
88. DATA REPORT: GEOCHEMICAL LOGGING RESULTS FROM THE SEA OF JAPAN: SITES 798 AND 7991
}

\author{
James F. Bristow, ${ }^{2}$ Cristina Broglia,${ }^{3}$ Peter B. deMenocal,${ }^{3}$ and Elizabeth Lewis Pratson ${ }^{3}$
}

\begin{abstract}
Geochemical well logs were obtained in the sedimentary sequences drilled at Sites 798 and 799 in the Sea of Japan. The recorded data have been corrected for variations in borehole size, borehole fluid composition, downhole temperature, and logging speed and were processed to derive the concentration of the elements $\mathrm{Th}, \mathrm{U}$, and $\mathrm{Gd}$ and the dry weight percentages of oxides of the elements $\mathrm{Si}, \mathrm{Ca}, \mathrm{Al}, \mathrm{Fe}, \mathrm{Ti}$, and $\mathrm{K}$ at 0.1524 -m intervals ( $6 \mathrm{in}$.). The log-derived geochemistry shows fair agreement with XRF core measurements for Hole 798B.
\end{abstract}

\section{INTRODUCTION}

Leg 128 was the second of two Ocean Drilling Program (ODP) cruises devoted to probing the history of the Japan Sea. The unifying objectives of this cruise and that of Leg 127 were to assess the style and dynamics of rifting and marginal sea formation in a continental arc setting and to decipher the parallel paleoceanographic evolution of the sea. During Leg 128, two structural highs (Sites 798 and 799) and one basin site (Site 794) were drilled, with the basin site first occupied during Leg 127 . Overall, logging operations were highly successful; the geochemical logging tool string and three other logging strings were run in Holes 798B, 799A, and 799B. Only at Hole 794D was the logging program not completed because of poor hole conditions. Logging operations have been detailed in Ingle, Suyehiro, von Breymann, et al. (1990).

Geochemical logs provide continuous in-situ measurements of the major rock-forming elements at $0.1524-\mathrm{m}$ intervals $(6 \mathrm{in}$.) down the borehole. These provide a large data base of geochemical information unaffected by several problems that inhibit core-based studies, such as incomplete or preferential core recovery and core disturbance.

This report describes the basic principles of the geochemical tool configuration and the post-cruise processing techniques employed on the data. This is followed by a brief qualitative comparison of the geochemical logs with the lithologic description and available core data.

\section{GEOCHEMICAL LOGGING TOOL}

Nuclear geochemical logging involves three separate modes of gamma-ray spectroscopy to obtain a comprehensive elemental analysis of the formation. The geochemical logging tool (GLT) deployed in ODP operations consists of four tool components, as shown in Figure 1. At the top of the string is the natural gamma-ray spectrometry tool (NGT, a trademark of Schlumberger Inc.), which measures the spectrum of natural gamma radiation of the formation using a sodium iodide $(\mathrm{NaI})$ scintillation detector, from which the concentrations of potassium (K), thorium (Th), and uranium (U) are derived (Lock and Hoyer, 1971). This tool is positioned at the top of the tool string so that the measurement is taken before irradiation of the

\footnotetext{
${ }^{1}$ Tamaki, K., Suyehiro, K., Allan, J., McWilliams, M., et al., 1992. Proc. ODP, Sci. Results, 127/128, Pt. 2: College Station, TX (Ocean Drilling Program).

${ }_{2}$ Borehole Research, Department of Geology, University of Leicester, LE1 7RH, England.

${ }^{3}$ Borehole Research Group, Lamont-Doherty Geological Observatory of Columbia University, Palisades, NY 10964, U.S.A.
}

formation by the sources below. The second measurement of the tool string is made by the aluminium activation clay tool (AACT, a trademark of Schlumberger Inc.). This measures the gamma rays produced by delayed neutron activation induced by a ${ }^{252} \mathrm{Cf}$ (Californium) source, carried by a dual porosity compensated neutron tool (CNT-G) positioned above the AACT, from which the concentration of aluminium (Al) in the formation is derived (Scott and Smith, 1973). The gamma-ray spectrometry tool (GST), carried at the bottom of the tool string, consists of a "minitron" tritium source of pulsed $14 \mathrm{MeV}$ neutrons and a gamma-ray scintillation detector. Incident neutrons lose energy through scattering interactions and upon reaching thermal energies, are captured by elemental nuclei, causing the emission of gamma rays of capture. The spectrum of gamma rays detected can be used, in conjunction with elements derived from the NGT and AACT, to derive the weight percentages of the elements silicon $(\mathrm{Si})$, iron $(\mathrm{Fe})$, calcium (Ca), sulfur (S), titanium (Ti), and gadolinium (Gd). The GST also measures the contribution of chlorine $(\mathrm{Cl})$ and hydrogen $(\mathrm{H})$ to the detected spectrum, from both the borehole and the formation.

The only major elements in the formation not measured by the geochemical tool string are magnesium $(\mathrm{Mg})$ and sodium $(\mathrm{Na})$. Neither of these elements has a sufficiently large capture cross section (relative to the typical cross section) to be detected by the GST (Hertzog et al., 1989). An estimate of their concentrations can be derived from the photoelectric factor (PEF) from the lithodensity tool. The recorded PEF log is compared to a computed PEF derived from a summation of the photoelectric contributions from the GLT-measured elements. Any difference is attributed to unmeasured elements in the formation (i.e., $\mathrm{Mg}$ and $\mathrm{Na}$ ). This calculation was performed on data from Sites 798 and 799 , but it only induced noise into the elemental calculation and was therefore omitted.

\section{DATA REDUCTION}

During logging operations aboard the JOIDES Resolution, the data are transmitted electronically up the conductive logging cable and recorded digitally in the Schlumberger cyber service unit (CSU). Some preliminary processing of the data occurs at this time to produce "field logs" that are immediately available to the shipboard scientific party for initial interpretation. Subsequent post-cruise processing on shore allows for more comprehensive environmental corrections for borehole size, logging speeds, borehole fluid salinity, temperature, and pipe effects. Processing of the GST spectrometry data is required to transform them into elemental oxide weight fractions.

The processing is performed using a series of programs written by Schlumberger Inc.; these are described in the following discussion. The processing flow is summarized in Figure 2. 


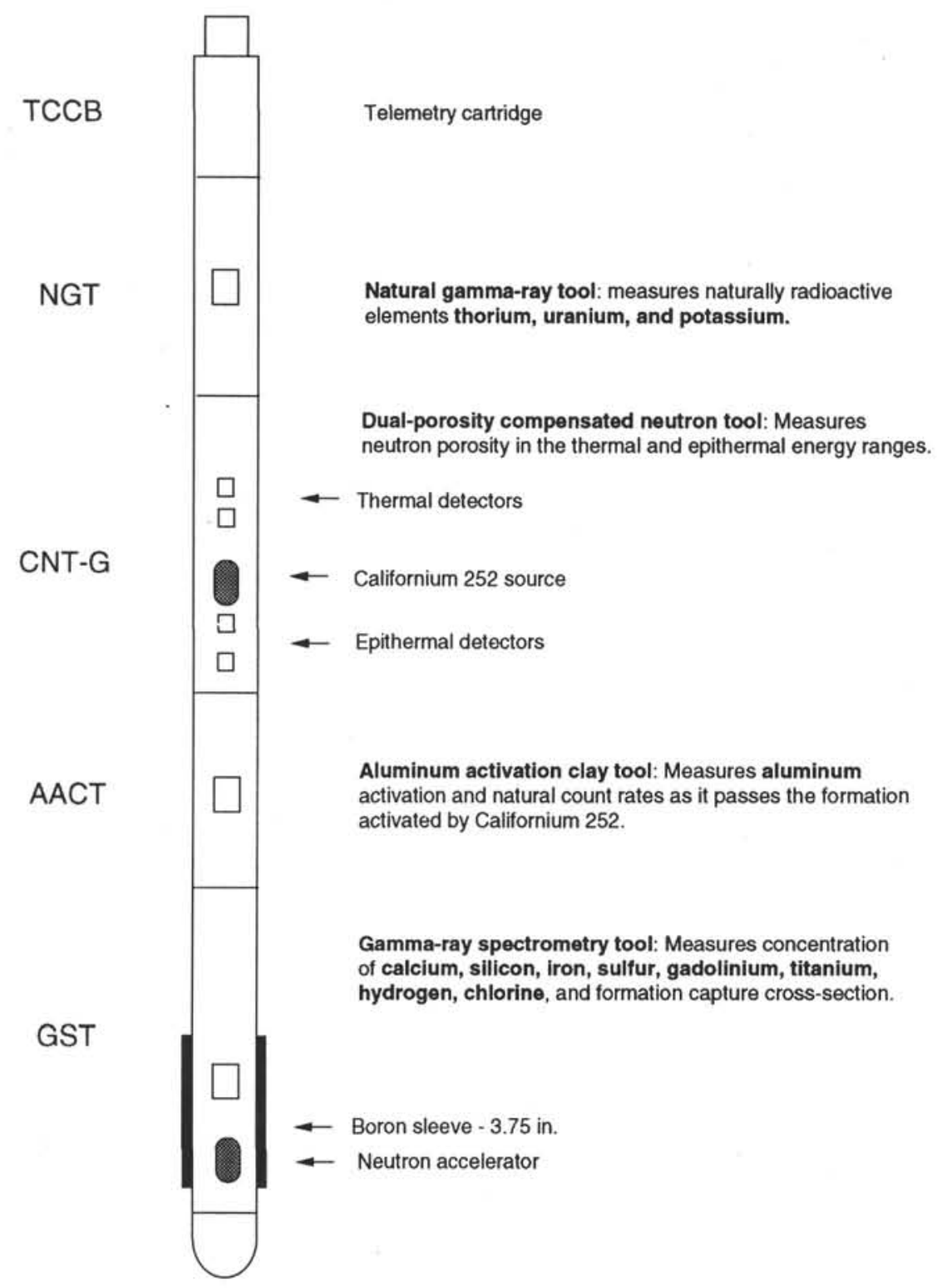

Figure 1. Schematic drawing of the geochemical logging string used in operations.

\section{Reconstruction of the Relative Elemental Yields from the Recorded Spectra}

The first step in the processing takes the measured spectra from the GST and determines the relative contribution of each element (yield) to the total recorded spectrum. The basic model of this program assumes that each downhole spectrum can be represented as a linear combination of a set of "standards," or basis spectra. These standards approximate the spectrum of each element and are combined with the recorded spectrum in a weighted least-squares inversion at each depth level to determine the relative elemental yields.

Shipboard CSU processing has a standard six-element inversion that solves for $\mathrm{Si}, \mathrm{Ca}, \mathrm{Cl}, \mathrm{H}, \mathrm{S}$, and $\mathrm{Fe}$ only. These six elements provide a useful framework for initial shipboard interpretation. Post-cruise processing typically utilizes the additional spectra of $\mathrm{Ti}, \mathrm{Gd}$, and $\mathrm{K}$, which have been shown to improve the fit of the elements to the recorded spectra substantially (Grau and Schweitzer, 1989). It is possible to remove and substitute other standards (elements) at this stage of the fitting process. In some environments logged by ODP, certain elements are below the detection resolution of the tool (Jarrard and Lyle, 1991). This is more often the case in high-porosity environments, where most of the detected gamma-ray spectrum is derived from chlorine and hydrogen in the formation and borehole, rather than from the rock matrix. Through experimentation, we found that sulfur was below the resolution of the GST in all holes, as was calcium in Holes 798B and 799A. These unresolved elements were found to introduce instability into the inversion, which induced significant noise in the remaining elements; thus, they were omitted from the calculation of the elemental yields.

A simple moving arithmetic average of 7-point ( $3.5 \mathrm{ft})$ in Holes 798B and 799B and 10-point (5 ft) in Hole 799A was applied to the output elemental yields to reduce noise levels in spectral data. Two complete runs of the geochemical string were done in Hole 798B; the yields from the two runs were combined by lateral averaging, which much improved the count statistics and reduced noise. 


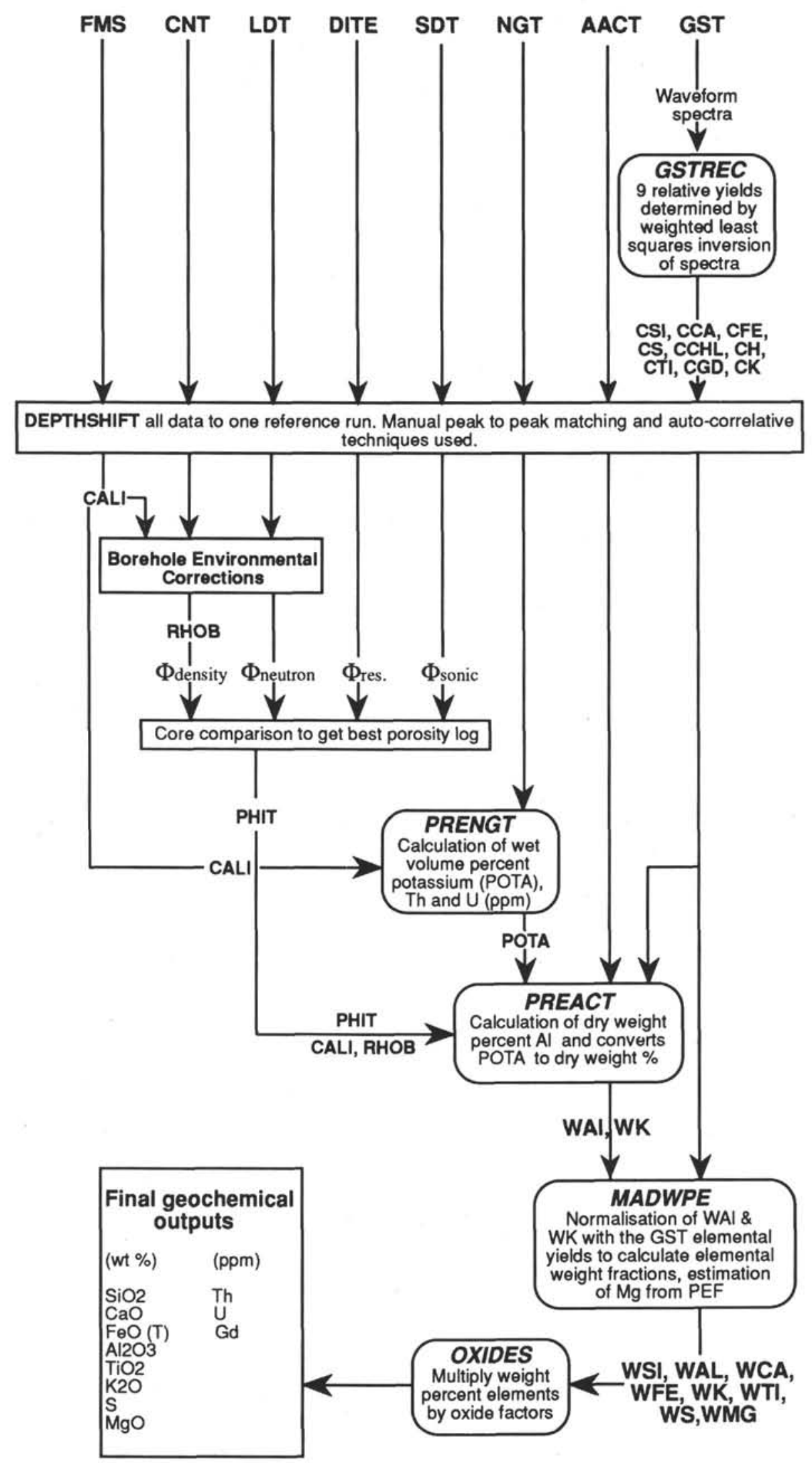

Figure 2. Flow diagram summarizing the post-cruise processing of the geochemical logging data. Schlumberger logging tool acronyms: FMS = formation microscanner, $\mathrm{CNT}=$ compensated neutron tool, $\mathrm{LDT}=$ lithodensity tool, DITE = dual induction tool, SDT = digital sonic tool, NGT = natural gamma-ray spectrometry tool, AACT $=$ aluminium activation clay tool, $\mathrm{GST}=$ gamma-ray spectrometry tool. $\mathrm{CALI}=$ caliper, $\mathrm{RHOB}=$ bulk density . Processing routine names are in bold italics. 


\section{Depth Shifting}

Geochemical processing involves the integration of data from different tool strings; consequently, it is important that all the data are depth-correlated to one reference logging run. This is done using the natural gamma-ray curve from the NGT (run on each tool string); the reference run is selected on the basis of cable tension, which indicates the degree of tool sticking, and the speed of the logging run. Faster logging runs are less susceptible to data degradation caused by the effect of the ship's vertical motion (heave) during logging, which has been shown not to be completely neutralized by the use of ODP's wireline heave motion compensator (Goldberg, 1990).

Data were depth-referenced to the seismic stratigraphic string for Hole 798B and to the geochemical string for Hole 799B. Data from Hole 799A required no depth shifting.

\section{Calculation of K, Th, and U from NGT Data}

This routine calculates the concentrations of $\mathrm{K}$, Th, and $\mathrm{U}$ from the natural gamma radiation spectrum detected by the NGT (Lock and Hoyer, 1971). This spectrum is divided into five discrete energy windows, with the three windows at the high-energy end covering a characteristic peak of the three radioactive series. Relatively few counts are seen in the high-energy range, where peak discrimination is best, thus a contribution from the high-count-rate, low-energy part of the spectrum is included to improve the count statistics. The counts from the five energy windows are inverted at each depth level to give the concentrations of $\mathrm{K}$, Th, and $\mathrm{U}$. This procedure is done while at sea, but is improved onshore by the inclusion in the calculation of caliper and temperature logs. The onshore calculation also corrects for $\mathrm{K}$ present in the borehole fluid, as was the case at each of the logged sites, where $2 \%$ potassium chloride was added to the borehole fluid to inhibit clay swelling. A moving 7-point $(3.5 \mathrm{ft})$ filtering window was applied to the raw input data to reduce statistical errors in the logs. The outputs of this program are $\mathrm{K}$ (wet wt\%), Th (ppm), and $\mathrm{U}$ (ppm), along with a total gamma-ray curve and a computed gamma-ray curve $(\mathrm{Th}+\mathrm{K})$. Although the NGT is run on all of the tool strings, the data shown for each of the logged holes (Figs. 3,6, and 8) are taken from the geochemical tool run, as this is performed at the lowest logging speed and, hence, provides the best count statistics.

\section{Calculation of Aluminium Concentration}

The fourth routine calculates the concentration of aluminium in the formation using data recorded by the AACT. This tool performs corrections on the raw data for borehole fluid and formation capture cross section (derived from the GST), formation slowing-down length, formation density, and borehole size. Count rates of gamma rays from the AACT are combined with those from the NGT to subtract out the background radiation; the concentration of $\mathrm{Al}$ is derived from the residual. The measurement is highly dependent on the ${ }^{252} \mathrm{Cf}$ neutron source strength, which is calculated by the routine from calibration data.

After the calculation of wet weight percent $\mathrm{Al}$, density and porosity logs are used to convert both $\mathrm{Al}$ and $\mathrm{K}$ (from the previous routine) to dry weight percent. For Holes 798B and 799A, a porosity curve was derived from the lithodensity tool, using matrix density determined from shipboard core measurements (Shipboard Scientific Party, 1990a, 1990b). The porosity curve from the neutron porosity tool was used for Hole 799B as it showed good agreement with core porosity measurements.

Finally, a correction is made for aluminium produced by fast neutron interactions with silicon, which occur when silicon becomes activated by the ${ }^{252} \mathrm{Cf}$, causing a reaction that produces the isotope, ${ }^{28} \mathrm{Al}$. The AACT data are combined with the elemental yields from the GST and $\mathrm{K}$ to determine the background silicon interference, which then is subtracted from the $\mathrm{Al} \log$. The program outputs $\mathrm{Al}$ and $\mathrm{K}$ data, which are used in the following closure model.

\section{Conversion of Elemental Yields to Elemental Weight Fractions (Hertzog et al., 1989)}

Relative concentrations of the GST-derived elemental yields can be determined by dividing each elemental yield by a relative spectral sensitivity factor, $S_{\mathrm{i}}$. This factor is principally related to the thermal neutron capture cross sections of the various elements. The relative elemental concentrations are related to the desired absolute concentrations by a depth-dependent normalization factor, $F$, as defined by the relationship:

$$
W t_{\mathrm{i}}=F Y_{\mathrm{i} /} \mathrm{S}_{\mathrm{i}} \text {, }
$$

where $W t_{\mathrm{i}}=$ absolute elemental concentration, $F=$ normalization factor, $Y_{\mathrm{i}}=$ relative elemental yield, and $S_{\mathrm{i}}=$ spectral sensitivity factor.

The normalization factor is calculated on the basis that the sum of all the elemental weight fractions is unity $(100 \%)$. The closure model handles the absence of carbon and oxygen, which are not measured by this tool string, with the approximation that each of the measurable elements combines as a single oxide or carbonate. The dry weight percentages of $\mathrm{Al}$ and $\mathrm{K}$ are normalized with the reconstructed elemental yields to determine the normalization factor at each depth interval from the following equation:

$$
F\left[\sum_{i} X_{i} Y_{i} / S_{i}\right]+X_{K} W t_{K}+X_{A l} W t_{A l}=1,
$$

where $X_{\mathrm{i}}=$ weight of oxide or carbonate/weight of element $i$, and the subscripts $\mathrm{K}$ and $\mathrm{Al}$ refer to the potassium and aluminium components.

By the nature of the closure relationship involving only elements in the rock matrix, no contribution from the borehole or pore fluids needs to be taken into consideration. The model compensates for tool standoff and washouts by automatically increasing the normalization factor.

\section{Calculation of Oxide Percentages}

The final routine converts the elemental weight percentages into oxide percentages by multiplying each element by its associated oxide factors, as shown in Table 1.

\section{RESULTS: DATA QUALITY AND COMPARISONS WITH CORE}

\section{Site 798}

The processed NGT data are shown in Figure 3 and are taken from the first run of the geochemical tool. The data were recorded openhole from 495 to $85 \mathrm{~m}$ below seafloor (mbsf). The most notable feature is the highly cyclic nature of the total gamma-ray log, particularly in the upper portion of the hole. This reflects a variation in opal and clay components of the formation that is thought to be driven by Milankovich cyclicity (Shipboard Scientific Party, 1990a).

The processed oxide data from the GST are shown in Figure 4. The lithologic variation downhole is limited, as reflected by the fairly uniform large-scale variation of the oxide logs. The "noisy" nature of the logs from 85 to 115 mbsf is an indication of unstable results, probably caused by the larger diameter of the borehole just below the end of the pipe, which results in fewer capture gamma rays detected from the formation. Lithologic Unit III, which represents the downward phase transition into opal-CT-bearing lithology, is marked by a slight increase in the $\mathrm{SiO}_{2}$ and a decrease in the $\mathrm{Al}_{2} \mathrm{O}_{3}$ log.

Figure 5 shows a comparison of log-derived oxides to X-ray fluorescence (XRF) measurements from core data. The agreement is generally fair to good. The logging data tend to exhibit more variance than the core data, and $\mathrm{TiO}_{2}$ is consistently overestimated by the logs. 
A detailed study of the core and log comparison is given by Bristow and deMenocal (this volume).

\section{Site 799}

Geochemical logs were recorded openhole from 80 to $450 \mathrm{mbsf}$ in Hole 799A and 1010 to $440 \mathrm{mbsf}$ in Hole 799B. The processed gammaray data from Holes 799A and 799B are shown in Figures 6 and 8, respectively. The total gamma-ray log generally reflects the changing clay content of the formation, which is in agreement with the lithologic core description (Shipboard Scientific Party, 1990b). The prominent rhyolitic tuff breccia in lithologic Unit IV of Hole 799B is very well defined by the high content of Th exhibited in the log.

Figures 7 and 9 display the oxide weight fractions from the logs for Holes 799A and 799B, respectively. Although no core oxide data are shown in Figure 7, data recently received suggest that the $\log \mathrm{Al}_{2} \mathrm{O}_{3}$ data for Hole $799 \mathrm{~A}$ are too high. This was caused by a problem encountered during processing and can be calibrated and corrected when additional core XRF data are available. As a consequence of the high $\mathrm{Al}_{2} \mathrm{O}_{3}$ percentage, the remaining oxides are slightly too low. This is most noticeable in the $\mathrm{SiO}_{2} \log$, in comparison with the $\mathrm{SiO}_{2}$ values in Hole 799B. In Hole 799B, the data from 440 to 600 mbsf show some noisy data values, particularly in the $\mathrm{CaO} \log$. Dolomite layers are well defined in the lower part of lithologic Unit III and in Unit IV by high $\mathrm{CaO}$ and low $\mathrm{SiO}_{2}$ values.

\section{REFERENCES}

Goldberg, D., 1990. Test performance of the Ocean Drilling Program wireline heave motion compensator. Sci. Drill., 1:206-209.
Grau, J. A., and Schweitzer, J., 1989. Elemental concentrations from thermal neutron capture gamma-ray spectra in geological formations. Nucl. Geophys., 3:1-10.

Hertzog, R., Colson, L., Seeman, B., O'Brien, M., Scott, H., McKeon, D., Grau, J., Ellis, D., Schweitzer, J., and Herron, M., 1989. Geochemical logging with spectrometry tools. SPE Form. Eval., 4:153-162.

Ingle, J. C., Jr., Suyehiro, K., von Breymann, M. T., et al., 1990. Proc. ODP, Init. Reports, 128: College Station, TX (Ocean Drilling Program).

Jarrard, D. R., and Lyle, M., 1991. High-resolution geochemical variations at ODP Sites 723, 728 and 731: a comparison of X-ray fluorescence and geochemical logs. In Prell, W. L., Niitsuma, N., et al., Proc. ODP, Sci. Results, 117: College Station, TX (Ocean Drilling Program), 473-498.

Lock, G. A., and Hoyer, W. A., 1971. Natural gamma-ray spectral logging. Log Analyst, 12:3-9.

Scott, H. D., and Smith, M. P., 1973. The aluminum activation log. $\log$ Analyst, 14:3-12.

Shipboard Scientific Party, 1990a. Site 798. In Ingle, J. C., Jr., Suyehiro, K., von Breymann, M. T., et al., Proc. ODP, Init. Repts., 128: College Station, TX (Ocean Drilling Program), 121-236.

1990b. Site 799. In Ingle, J. C., Jr., Suyehiro, K., von Breymann, M. T., et al., Proc. ODP, Init. Reports, 128: College Station, TX (Ocean Drilling Program), 237-652.

Date of initial receipt: 18 March 1991

Date of acceptance: 12 November 1991

Ms 127/128B-222 

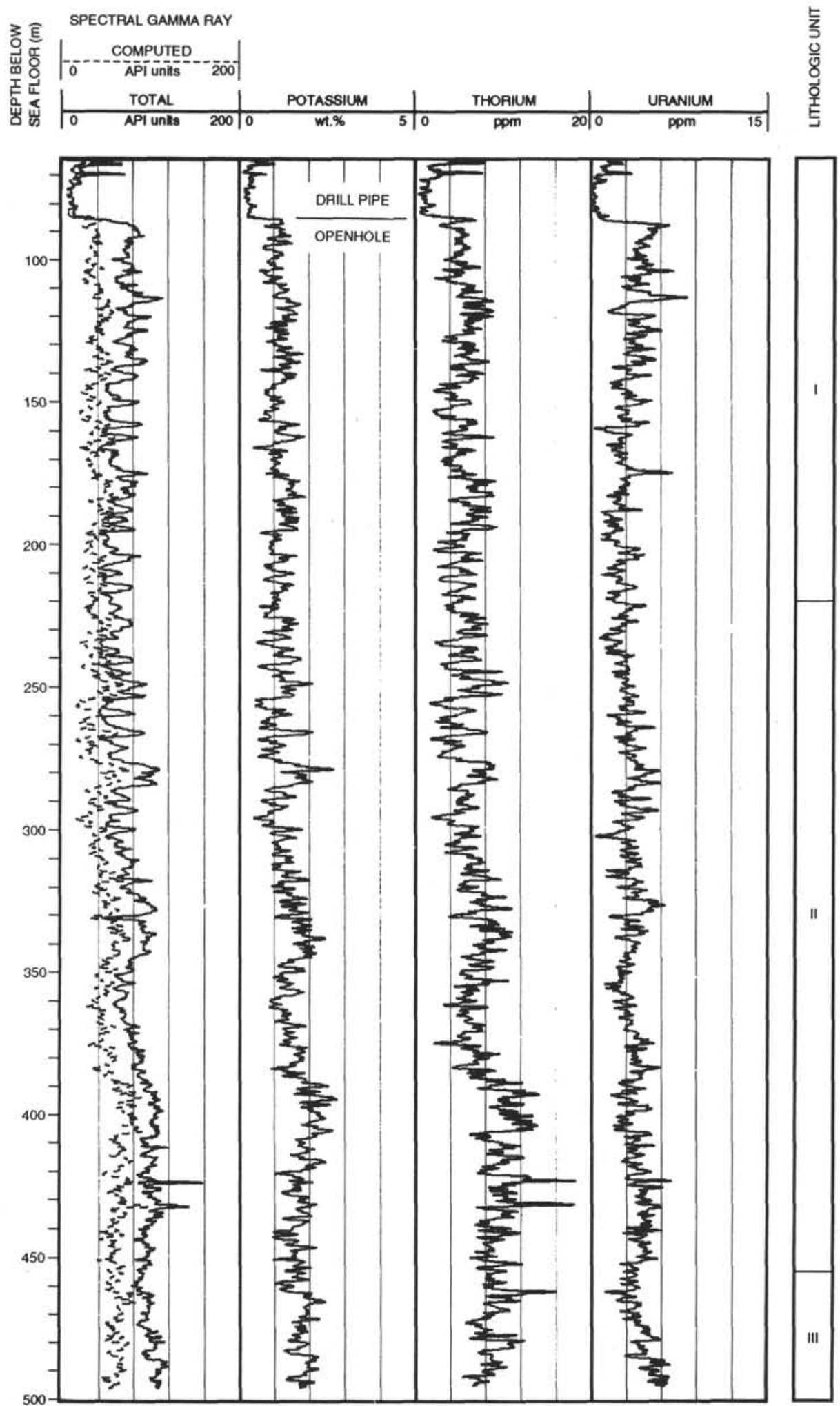

Hole 798B: legend of lithologic units

Unit I. Clay, silty clay, and diatomaceous clay

Unit II. Diatomaceous clay interbedd with diatom ooze and silty clay

Unit III. Siliceous claystone and claystone with varable amounts of glauconite and quartz

Figure 3. Processed natural gamma-ray data from the NGT for Hole 798B. 


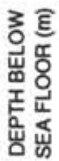

\begin{tabular}{|l}
$\mathrm{SiO}$ \\
\hline 0
\end{tabular}

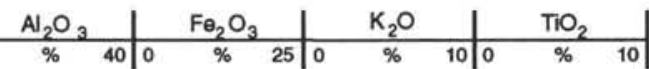

\section{$\frac{5}{5}$
0
$\frac{0}{8}$
8
준
5}

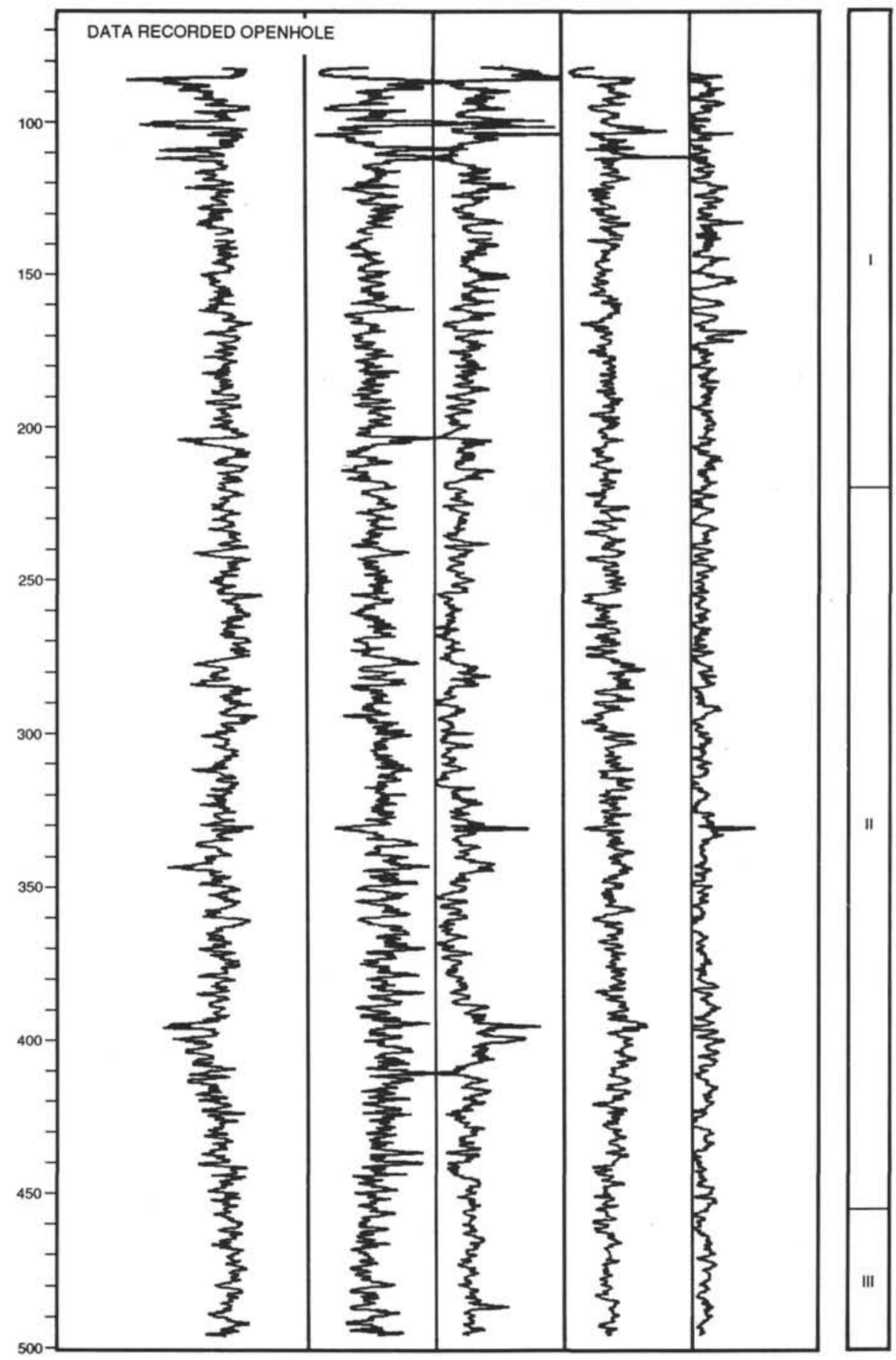

Figure 4. Estimates of the dry weight percentage of major oxides derived from the geochemical logging tool for Hole 798B. See Figure 3 for lithology. 

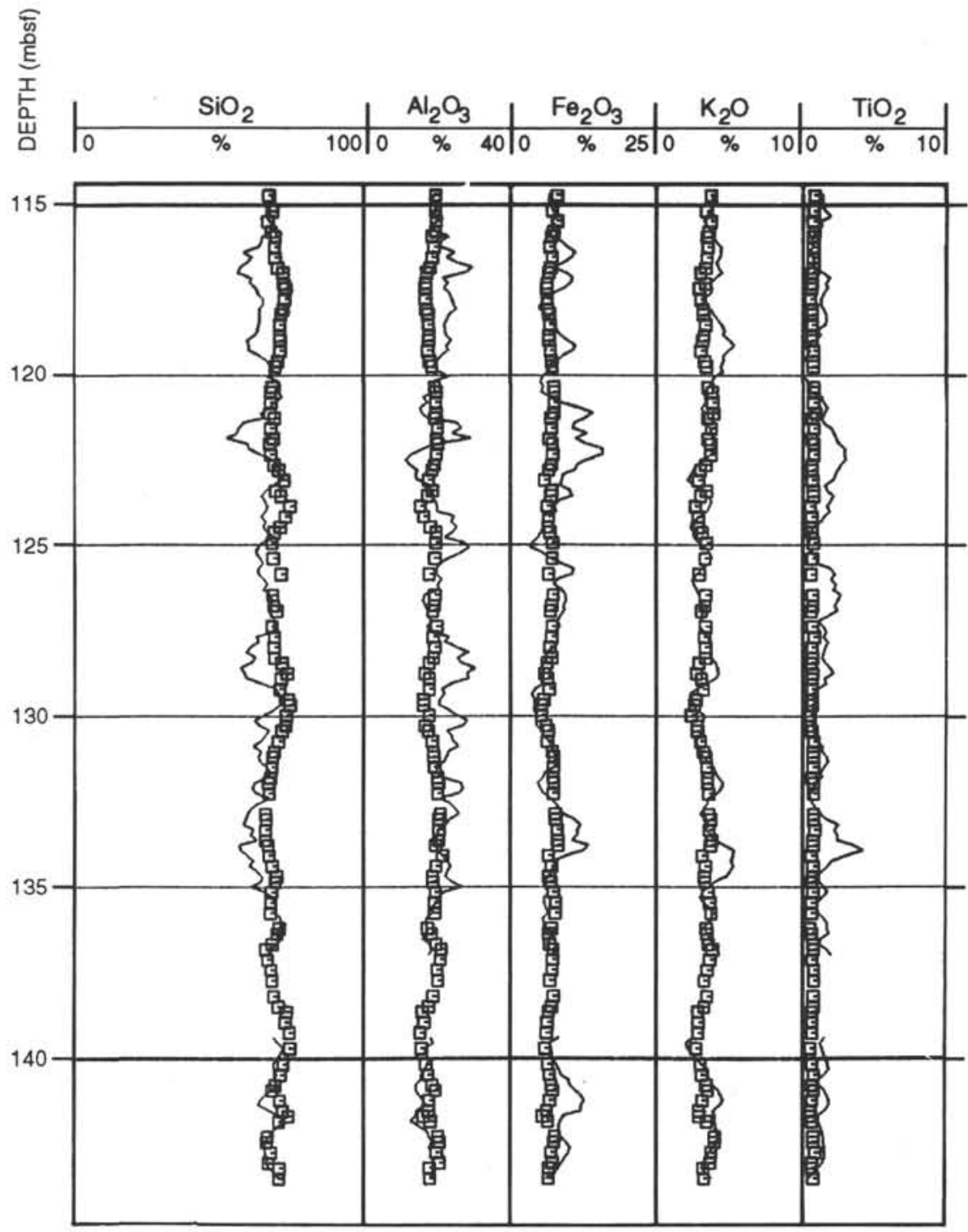

Figure 5. Comparison of oxides for a section of Hole 798B, derived from the geochemical logging tool (line) and XRF analyses of core data (squares).

Table 1. Oxide factors for closure normalization.

\begin{tabular}{clc}
\hline Element & Oxide & Conversion factor \\
\hline $\mathrm{Si}$ & $\mathrm{SiO}_{2}$ & 2.139 \\
$\mathrm{Ca}$ & $\mathrm{CaO}$ & 1.399 \\
$\mathrm{Fe}$ & $\mathrm{FeO}$ (total & 1.358 \\
& $\mathrm{Fe}$ ) & \\
$\mathrm{K}$ & $\mathrm{K}_{2} \mathrm{O}$ & 1.205 \\
$\mathrm{Ti}$ & $\mathrm{TiO}_{2}$ & 1.668 \\
$\mathrm{Al}$ & $\mathrm{Al}_{2} \mathrm{O}_{3}$ & 1.899 \\
\hline
\end{tabular}



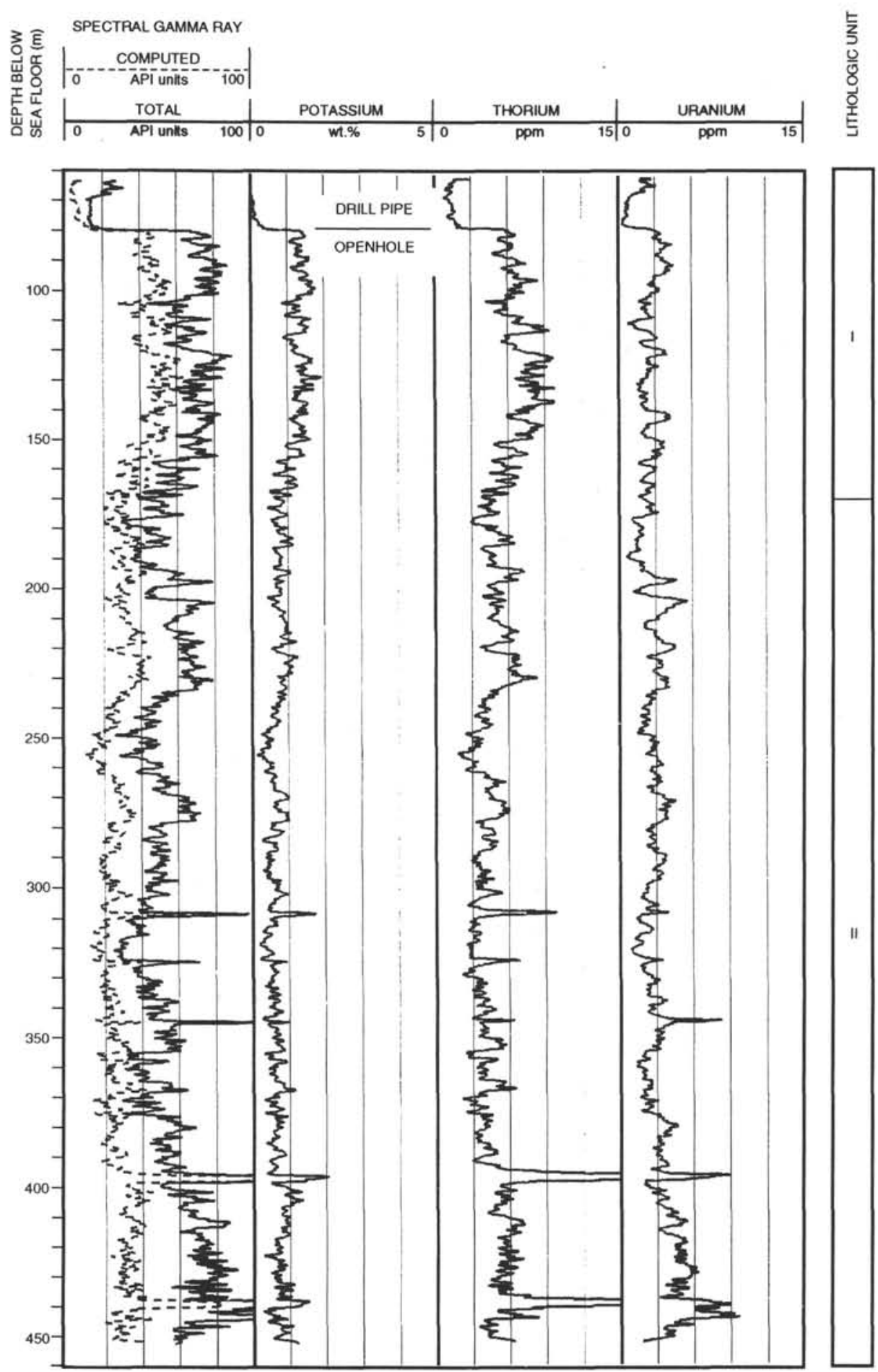

Hole 799A: legend of lithologic units

Unit I. Diatomaceous clay/ooze, silt, and clay

Unit II. Diatomaceous ooze to diatomaceous clay

Figure 6. Processed natural gamma-ray data from the NGT for Hole 799A. 

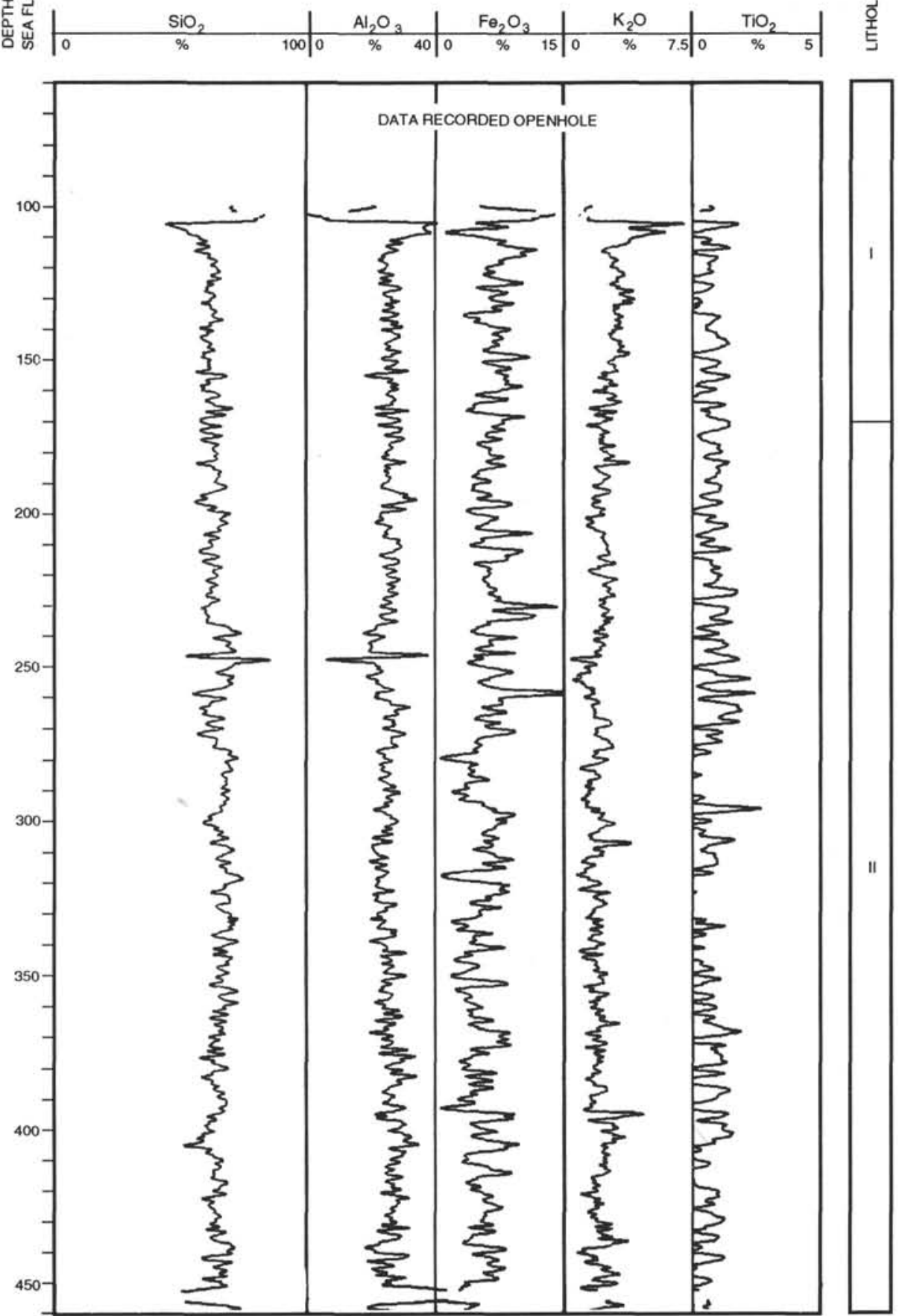

Figure 7. Estimates of the dry weight percentage of major oxides, derived from the geochemical logging tool for Hole 799A. See Figure 6 for lithology. 
[Blank page] 

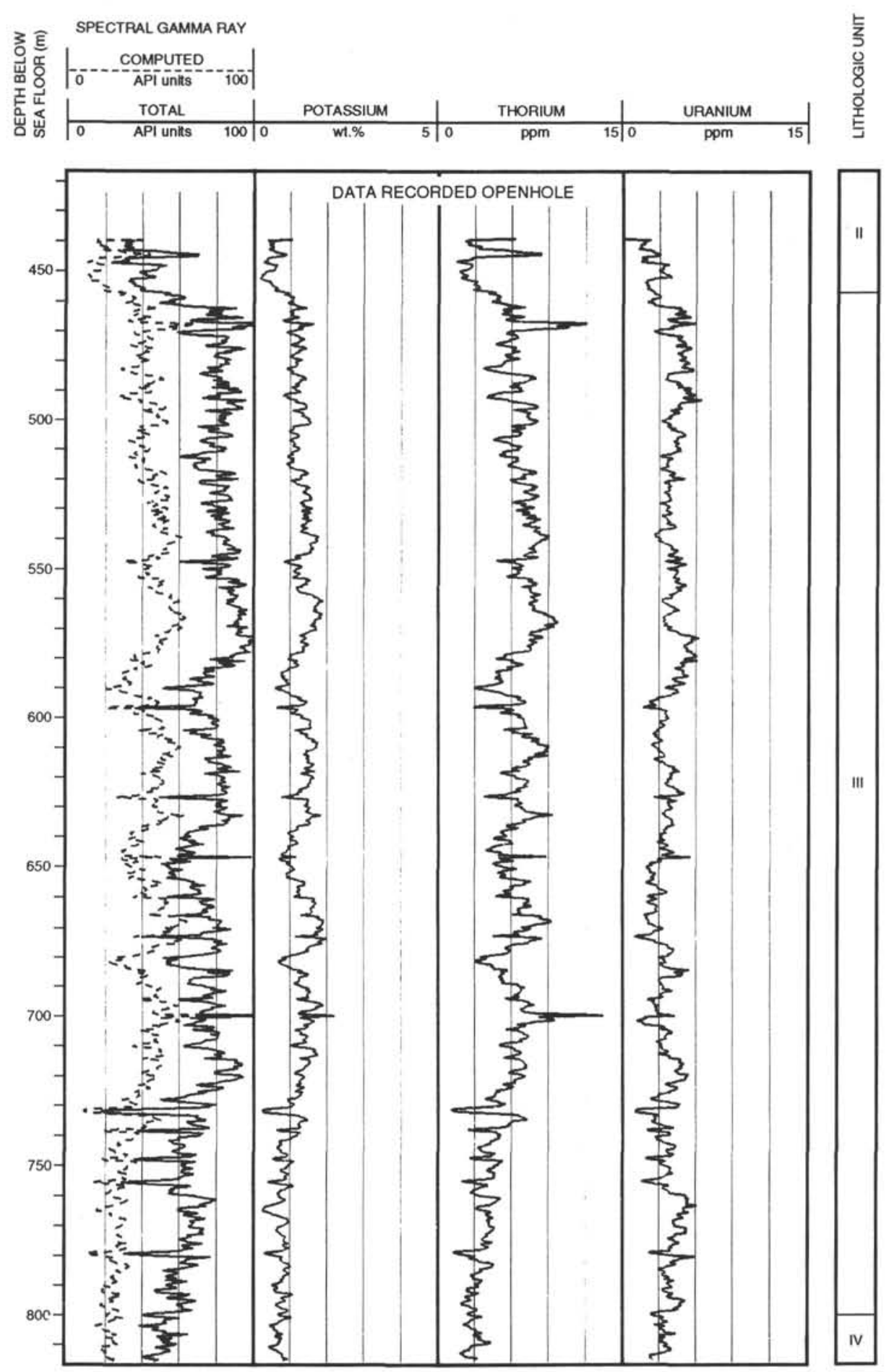

Figure 8. Processed natural gamma-ray data from the NGT for Hole 799B. 

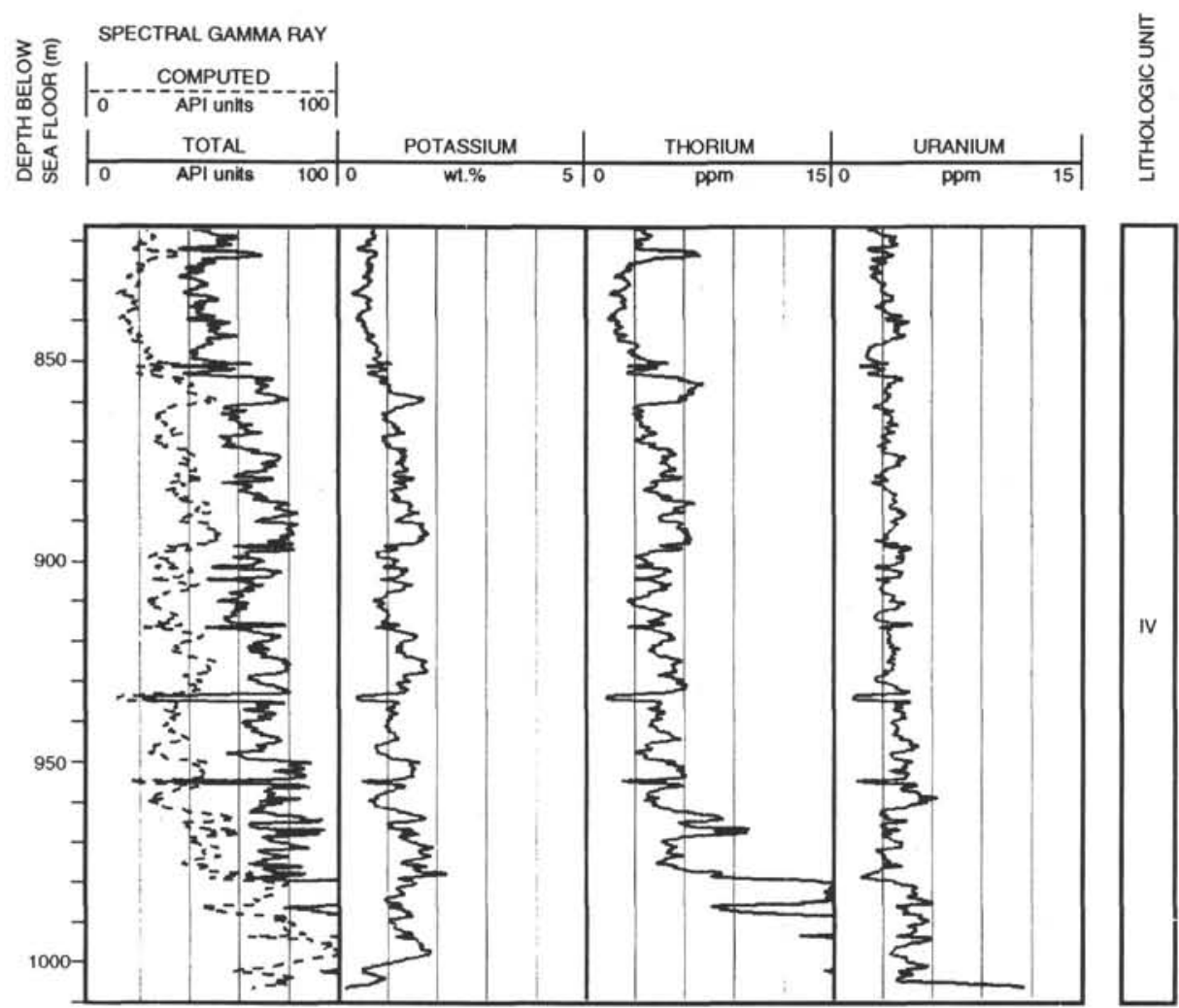

Hole 799B: legend of lithologic units

Unit III. Siliceous claystone and porcellanite intercalated with laminae of authigenic carbonate

Unit IV. Siliceous claystone and porcellanite intercalated with carbonate-rich laminae

Unit V. Siliceous claystone and claystone with silt with intercalations of sand and sandstone

Figure 8 (continued). 

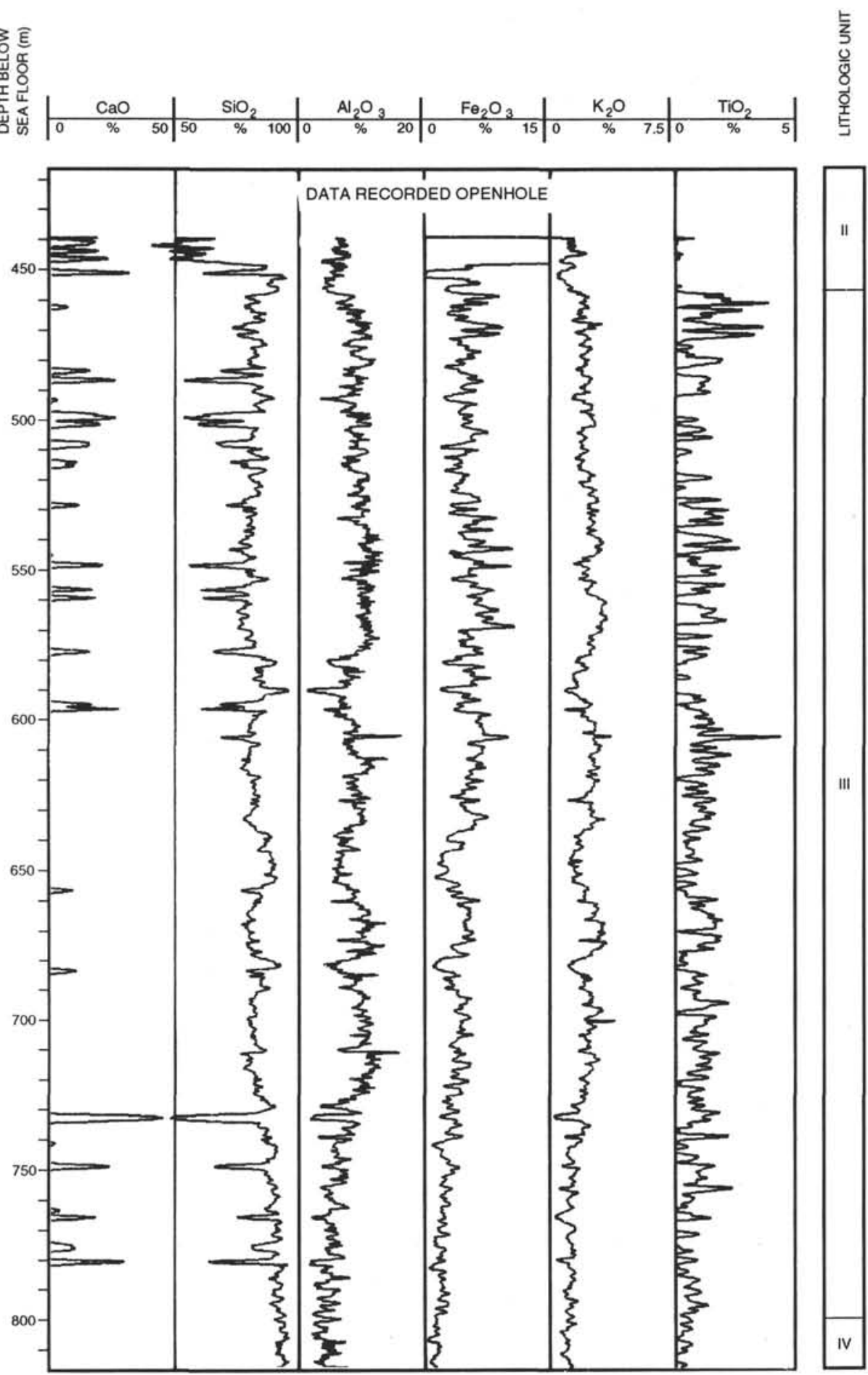

Figure 9. Estimates of the dry weight percentage of major oxides, derived from the geochemical logging tool for Hole 799B. See Figure 8 for lithology. 

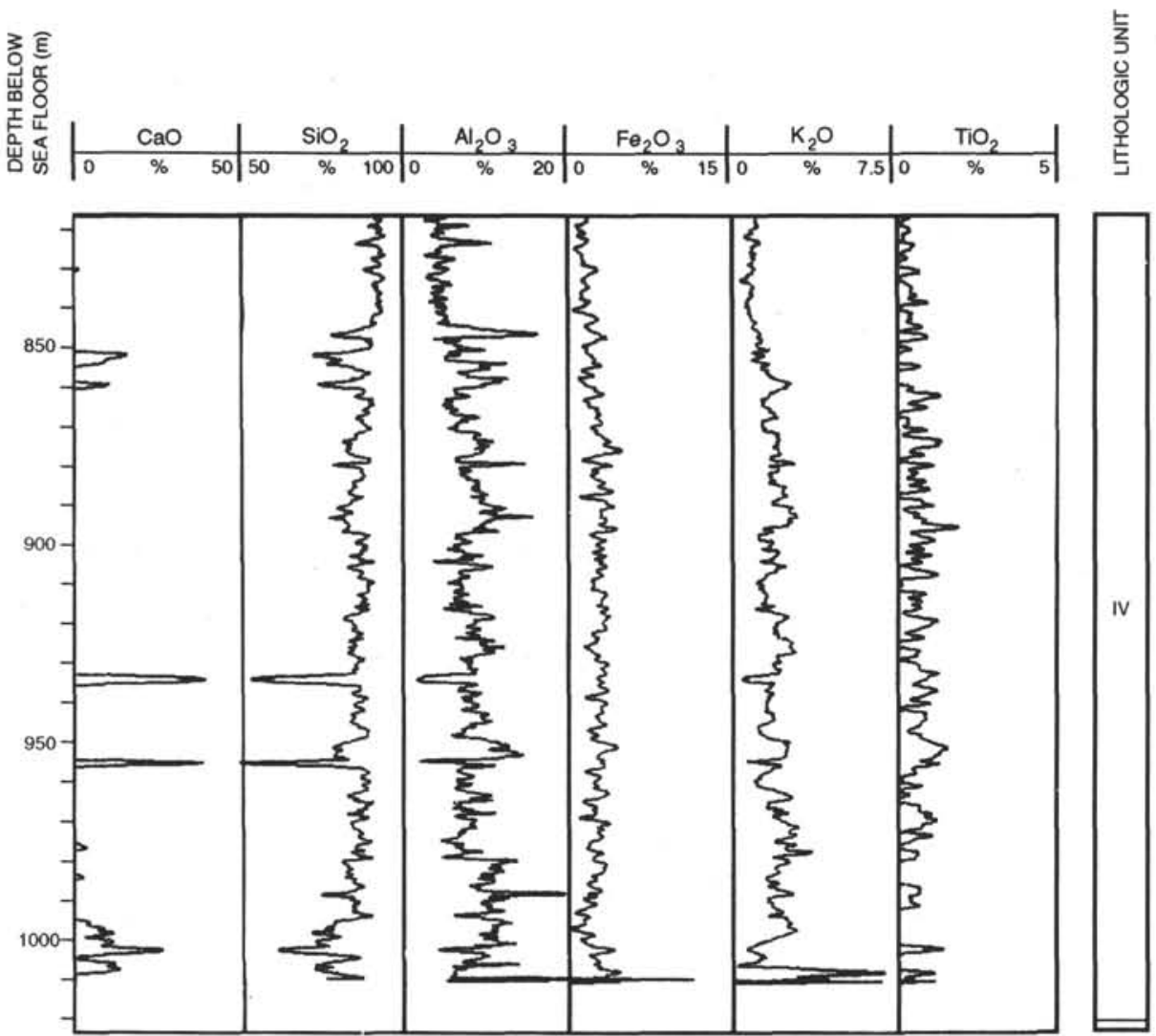

Figure 9 (continued). 